\title{
Bioedusiana
}

http://jurnal.unsil.ac.id/index.php/bioed/index

DOI: https://doi.org/10.34289/285230

\section{PERBANDINGAN PENGETAHUAN BIODIVERSITAS DAN SIKAP PEDULI \\ LINGKUNGAN ANTARA PESERTA DIDIK DI SEKOLAH KAWASAN \\ TAMAN NASIONAL WAY KAMBAS DAN KAWASAN PERKOTAAN \\ Comparison of Biodiversity and Environmental Care Attitudes Between Students at Way Kambas National Park and Urban Area}

\author{
Sulastri Fauziah ${ }^{1)}$, Arwin Surbakti ${ }^{1)}$, Darlen Sikumbang ${ }^{1)}$ \\ ${ }^{1)}$ Pendidikan Biologi FKIP Universitas Lampung, Jl. Prof. Dr. Soemantri Brojonegoro No. 1 Bandar \\ Lampung 35145, Indonesia \\ Email korespondensi: astiasti78@gmail.com
}

\section{Info Artikel}

Sejarah Artikel:

Diterima: 22 Mei 2019

Disetujui : 27 Mei 2019

Dipublikasikan: 30 Juni

2019

\section{Keywords:}

Pengetahuan biodiversitas,

sikap peduli lingkungan,

Taman Nasional Way

Kambas (TNWK)

\begin{abstract}
Abstrak
Penelitian ini bertujuan menentukan perbandingan pengetahuan biodiversitas dan sikap peduli lingkungan antara peserta didik di Sekolah Kawasan TNWK dengan di Kota Bandar Lampung. Pengambilan sampel menggunakan random sampling.Desain penelitian adalah ex post facto. Data penelitian diperoleh dari tes dan kuisioner, kemudian dianalisis menggunakan uji t. Hasil penelitian menunjukan terdapat perbedaan antara pengetahuan biodiversitas dan sikap peduli lingkungan antara sekolah kawasan TNWK dengan sekolah di kota Bandar Lampung. Hasil uji regresi linier sederhana menunjukan terdapat hubungan antara pengetahuan tentang biodiversitas terhadap sikap peduli lingkungan peserta didik di Sekolah Kawasan TNWK. Temuan lainnya yaitu pengetahuan tentang biodiversitas peserta didik di sekolah Kota Bandar Lampung tidak terdapat pengaruh terhadap sikap peduli lingkungan.

\section{Abstract}

This study aims to determine the comparison of biodiversity knowledge and environmental care attitude between students in the TNWK Regional School and in Bandar Lampung City. Sampling uses random sampling. The research design is ex post facto. The research data was obtained from tests and questionnaires, then analyzed using the t test. The results showed that there was a difference between biodiversity knowledge and environmental awareness between the TNWK area school and the school in Bandar Lampung city. The results of a simple linear regression test showed that there has relationship between knowledge about biodiversity towards the environmental care attitude of students in the TNWK Regional School. The knowledge of the biodiversity of students in Bandar Lampung City schools has no effect on environmental care.
\end{abstract}

(C) 2019 Universitas Siliwangi

\footnotetext{
Alamat korespondensi:

Jurusan Pendidikan Biologi FKIP Universitas Siliwangi

Gedung Perkantoran FKIP Lt. 3

Jalan Siliwangi No. 24 Kota Tasikmalaya 46115

HP. 08112344989 (a.n. Rinaldi Rizal Putra, M.Sc.)

E-mail: bioedusiana@unsil.ac.id
}

ISSN: 2477-5193 (Print) 


\section{PENDAHULUAN}

Lingkungan hidup adalah satu kesatuan dari suatu ruang yang terdiri dari benda, daya, keadaan dan makhluk hidup termasuk manusia di dalamnya yang membentuk suatu sistem dengan hubungan yang saling mempengaruhi untuk membentuk kelangsungan ke-hidupan dan kesejahteraan manusia serta makhluk hidup lain yang ada di dalam-nya. Hubungan saling ketergantungan antara semua elemen yang ada dalam sistem ini sangat penting diketahui terutama oleh manusia sebagai pengelola utama di dalam sistem ini agar ke-berlangsungan hubungan ini dapat terus dipertahankan untuk keberlanjutan sistem kehidupan di atas muka bumi (Bimber, 2003: 93).

Biodiversitas merupakan komponen sistem kehidupan yang penting, untuk menjaga ekosistem agar tetap stabil biodiversitas harus tetap dijaga. Pada ke-majuan teknologi seperti pada jaman sekarang, masyarakat bisa menjaga ke-seimbangan sumber daya dengan me-lakukan pelestarian. Biodiversitas atau Keanekaragaman hayati terdiri dari flora (tumbuhan) dan fauna (binatang) yang tersebar di seluruh Nusantara. Penyebaran flora dan fauna tersebut memiliki tingkat keragaman yang berbeda antara satu daerah dengan daerah yang lainnya. Biodiversitas atau Keanekaragaman hayati yang dimiliki oleh Indonesia merupakan kekayaan yang tak ternilai harganya sehingga perlu dilestarikan. Pelestarian keanekaragaman hayati dapat ditempuh melalui upaya konservasi (Kadous, $2000: 35$ ).

Eksploitasi yang berlebihan dapat menimbulkan krisis lingkungan dan biodiversitas atau kenanekaragaman hayati yang tak dapat dipisahkan dengan krisis etika dan moral masyarakat, karena keterlibatan masyarakat dalam pemanfaatan sumberdaya hayati secara berlebihan berdampak terhadap ber-kurangnya jenis sumberdaya hayati tersebut. Sikap peduli lingkungan atau perilaku masyarakat dalam konservasi cagar alam merupakan sebuah gejala sosial yang diduga terkait dengan ber-bagai faktor antara lain tingkat pendidikan, tingkat pendapatan, kearifan tradisional, kegemaran atau hobi yang merupakan bagian dari sikap hedonism, status sosial ekonomi, tanggung jawab lingkungan, partisipasi dalam aktivitas sosial, etika lingkungan, wawasan ekologis, keterpaan informasi, pe-mahaman tentang keanekaragaman hayati (Keraf, 2002: 59).

Sikap peduli lingkungan merupakan perilaku sadar lingkungan akan sangat tergantung kepada perkembangan mental dan kepribadian seseorang di samping faktor pengaruh dari lingkungan itu sendiri. Perilaku manusia juga merupakan hasil interaksi antara rangsang-an (stimulus) respon dan semua bentuk perilaku yang kompleks termasuk ke-biasaan, berpikir dan reaksi emosional yang dibentuk dari stimulus respon khusus yang dapat dilihat dan diukur sehingga dapatmemproduksi dan me-ngontrol perilaku seseorang jika kita mengontrol stimulus (Skinner, 2000: 93-94).

Sikap peduli lingkungan atau perilaku masyarakat terhadap lingkungan dapat ditingkatkan dengan edukasi atau pembelajaran salah satunya didapatkan dari pendidikan. Pendidikan pembangunan berkelanjutan adalah proses pendidikan untuk mencapai pembangunan manusia yang meliputi tiga pilar yaitu: pertumbuhan ekonomi, perkembangan sosial, dan perlindungan lingkungan. Ketiga pilar tersebut menjadi pedoman pendidikan lingkungan hidup di sekolah. Pendidikan lingkungan hidup tidak hanya diberikan pada kegiatan formal saja, akan tetapi dapat juga diberikan pada jalur nonformal seperti kegiatan Pramuka, Pecinta Alam, Palang Merah Remaja, Prokasih serta pembinaan dan pelatihan lingkungan di luar sekolah formal. Hal tersebut dikuatkan dalam Deklarasi Cimanggis pada tahun 2007 poin kedua bahwa salah satu cara meningkatkan pendidikan tentang alam dan lingkungan, melalui jalur formal (SD, SMP, dan SMA/SMK) maupun jalur nonformal untuk meningkatkan kecintaan masyarakat terhadap alam, lingkungan dan orang lain (Ismail, 2010: 811).

Pembelajaran Pendidikan Lingkung-an Hidup (PLH) tidak hanya berupa teori saja, akan tetapi harus benar-benar dipraktekan dan dicerminkan dalam ke-hidupannya sehari-hari, agar tertanam kesadaran dan kecintaan terhadap lingkungan. Pendidikan lingkungan hidup sudah lama diajarkan di sekolah-sekolah, akan tetapi dampak dan hasil pendidikan lingkungan hidup yang telah dilaksanakan di lembaga-lembaga pendidikan belum banyak terlihat, baik pada 
masyarakat maupun lingkungan (Hamzah, 2004: 20).

Pendidikan lingkungan hidup mengharapkan generasi muda yang sadar lingkungan serta selalu bertindak positif yang didasari lingkungan. Bahkan konferensi dunia UNESCO pada tahun 1977 di Tifflis memfokuskan pada "environ-mental education", sebagai bukti kepeduliannya pada pendidikan lingkungan untuk menghasilkan generasi mendatang yang sadar akan lingkungan. Implementasi pendidikan lingkungan hidup di Indonesia diberlakukan dari pendidikan dasar sampai pendidikan tinggi dalam bentuk Pendidikan Kependudukan dan Lingkungan Hidup (PKLH), Pendidikan Lingkungan Hidup (PLH), Sekolah Berbudaya Lingkungan (SBL), dan yang sekarang digalakkan berupa sekolah Adiwiyata, yang dikembangkan pe-merintah melalui kerjasama kementrian lingkungan hidup dan kementrian pen-didikan nasional (Afrianti, 2012: 16-18).

Konservasi (conservation) yang diartikan sebagai perlindungan yang lahir dari ide pembentukan lembaga perlindungan di Eropa Preservasi yang berarti pengawetan sisa-sisa hutan alam di Eropa (Wiratno dkk, 2001:14). Konservasi sumberdaya alam dewasa ini lebih diarahkan kepada konservasi keanekaragaman hayati. Hal ini disebabkan keanekaragaman hayati kini berada di ambang kepunahan. Menurut Chiras spesies yang terancam punah perlu diselamatkan didasarkan pada alasan, estetika, ekonomi dan stabilitas ekosisitem (Chiras, 1988: 34).

Salah satu kawasan konservasi di Indonesia yang lebih tepatnya terletak di Lampung yaitu Taman Nasional Way Kambas (TNWK) yang merupakan bentang alam kawasan ekosistem dengan luas 130.000 HA terletak di Provinsi Lampung yang membentang dari utara ke selatan, merupakan bentang alam kawasan hutan di bagian tenggara Sumatera. Di kawasan tersebut penting bagi perlindungan Badak Sumatera (Dicerorhinus sumatrensis sumatrensis) yang sangat terancam punah. Taman Nasional tersebut memiliki satu spektrum ekosistem yang besar, dimana di dalamnya dapat ditemui beberapa formasi hutan. Didasarkan pada tipe ekosistemnya, kawasan ini dapat dikelompokkan ke dalam lima tipe, yaitu hutan mangrove, pantai, riparian rawa, dan dipterocarpaceae dataran rendah (Rifanz, 2017).

Berdasarkan penelitian terdahulu yang dilakukan oleh Ade Haerullah dan Said Hasan yang dilaksanakan pada bulan November 2009 sampai bulan Februari 2010. Penelitian dilakukan di kawasan konservasi Cagar Alam Gunung Sibela. Hasil penelitian mengungkapkan bahwa sikap peduli lingkungan di daerah kawasan konservasi terbilang tinggi, begitu juga dengan pengetahuan biodiversitasnya. Masya-rakat dapat memanfaatkan dan melestarikan kawasan konservasi. Se-lanjutnya oleh Tri Sulistyo Saputro yang dilaksanakan pada bulan Februari 2013 di wilayah Hutan Kota Srengseng (HKS) Jakarta Barat. Hasil penelitian me-ngungkapkan bahwa masyarakat di kawasan konservasi tersebut telah memiliki tingkat sikap peduli lingkungan dan pengetahuan biodiversitas yang tinggi, hal ini disebabkan oleh faktor pe-nyuluhan dan pendidikan.

Sikap peduli lingkungan secara umum tidak selalu didorong oleh motif rasional semata maupun motif moral semata. Oleh karena itu diperlukan pendekatan alternatif yang memunculkan kerangka rasional dan moral secara bersama untuk menjelaskan faktor-faktor yang memengaruhi perilaku peduli lingkungan.Selain dari Kawasan Suaka Alam dan Kawasan Pelestarian Alam, di Indonesia juga ada hutan yang dilindungi berdasarkan Keputusan Menteri Kehutanan yaitu Hutan Lindung. Kawasan Hutan Lindung adalah hutan- hutan yang fungsinya untuk melindungi kawasan hutan sebagai sumberdaya air, tanah dan ekosisitemnya, sehingga dapat memberikan perlindungan pada sistem penyangga kehidupan (Indrawan, 2012: 61-67).

Sekolah yang dipilih sebagai objek penelitian kali ini yaitu SMA Negeri 1 Labuhan Maringgai karena SMA tersebut merupakan SMA yang terletak di kawasan dekat dengan kawasan konservasi, yaitu Taman Nasional Way Kambas (TNWK). Selain itu peneliti juga memilih SMA Negeri 14 Bandar Lampung yang merupakan SMA di Kota dan telah menerapkan program Adiwiyata di sekolah.

Berdasarkan wawancara dengan pendidik di SMA Negeri 1 Labuhan Maringgai dapat diketahui bahwa pendidikan lingkungan hidup 
sudah diintegrasikan dalam kurikulum. Penerapannya sudah cukup maksimal, hal ini dibuktikan dari hasil wawancara dengan pendidik yaitu banyaknya program yang berhubungan dengan ling-kungan, sehingga pendidik dan peserta didik berperan dalam pengelolaan lingkungan.

Pendidikan lingkungan hidup ter-sebut berpengaruh terhadap sikap peduli lingkungan peserta didik di sekolah tersebut. Di sekolah tersebut menerapkan program kegiatan yang berhubungan dengan alam, seperti pramuka, PLH, dan Pemula. Oleh karena giatnya kegiatan yang berhubungan dengan alam me-nyebabkan tingginya sikap peduli lingkungan peserta didik di sekolah tersebut.

Kemudian pendidikan lingkungan hidup dapat diintegrasikan dalam mata pelajaran, salah satunya adalah mata pelajaran biologi. Dalam mata pelajaran biologi tersebut teradapat materi bio-diversitas atau keanekaragaman hayati yang berhubungan dengan lingkungan yang terdapat dalam pelajaran formal maupun nonformal, sehingga dapat mengelola dan memelihara lingkungan sekolah secara bersih, asri, dan sejuk demi kenyamanan belajar dan ke-berlanjutan pembangunan.

Berdasarkan penelitian pendahuluan melalui angket yang diisi oleh siswa siswi serta guru SMA Negeri 14 Bandar Lampung dan SMA Negeri 1 Labuhan Maringgai serta melalui observasi dapat diketahui bahwa siswa siswi maupun guru di kedua SMA tersebut telah menerapkan pembelajaran lingkungan hidup dalam pelajaran formal maupun non-formal, bahkan pada Sekolah tersebut telah membentuk organisasi pecinta alam yang setiap kegiatannya berhubungan dengan alam dan menjaga lingkungan. Sehingga dapat dikatakan bahwa tingkat kepedulian terhadap lingkungan sudah cukup baik.

Berdasarkan latar belakang yang telah dikemukakan, maka peneliti sangat tertarik untuk melakukan penelitian untuk mengetahui kefektivitasan pendidikan lingkungan hidup disekolah dilihat dari pengetahuan dan sikap peduli lingkungan, maka dilaksanakan pe-nelitian dengan judul "Perbandingan Pengetahuan Tentang Biodiversitas dan Sikap Peduli Lingkungan Antara Peserta Didik di SMA N 1
Labuhan Maringgai dan SMAN 14 Bandar Lampung."

\section{METODE}

Penelitian ini menggunakan desain ex post facto (Sudaryono, Margono, dan Rahayu, 2013: 11) karena pada penelitian ini, peneliti mencari variabel bebas yang bersifat tidak dapat dimanipulasi dalam penelitian ini yaitu pengetahuan tentang keanekaragaman hayati dan sikap peduli lingkungan meyebabkan terjadinya perbedaan suatu tingkah laku kelompok individu dalam variabel terikat yaitu di sekolah sekitar kawasan Taman Nasional Way Kambas yaitu SMA Negeri 1 Labuhan Maringgai Kabupaten Lampung Timur dan sekolah di Kota Bandar Lampung yaitu SMA Negeri 14 Bandar Lampung. Seperti yang di jelaskan Nazir (2009: 73) bahwa ciri utama dalam desain penelitian $e x$ post facto yaitu peneliti tidak mempunyai kontrol langsung terhadap variabel-variabel bebas karena manfestasi fenomena telah terjadi atau fenomena sukar dimanipulasi. Dijelaskan lebih lanjut mengenai hal ini oleh Arikunto (2010: 268), peneliti tidak memulai prosesnya dari awal, tetapi langsung mengambil hasil. Metode yang digunakan dalam penelitian ini adalah deskriptif dengan pendekatan kuantitatif. Arikunto (2010: 3) mendefinisikan penelitian deskriptif sebagai penelitian yang dimaksudkan untuk menyelidiki keadaan, kondisi atau hal-hal lain dan hasilnya dipaparkan dalam bentuk laporan penelitian. Pendekatan kuantitatif yaitu dalam kegiatan penelitian ini data berupa nilai pengetauhan tentang biodiversitas dan sikap peduli lingkungan yang kemudian di uji pengaruh menggunakan uji regresi linier sederhana dan kemudian uji beda antara sekolah kawasan TNWK dan sekolah dikota Bandar Lampung dengan menggunakan uji independent sampel t test.

Pengetahuan biodiversitas peserta didik diukur menggunakan soal pilihan jamak yang berjumlah 22 pertanyaan meliputi tujuh indikator yaitu: Membedakan tingkatan keanekaragaman hayati tingkat gen, jenis dan ekosistem; Membedakan pengertian keseragaman dan keberagaman makhluk hidup; Menjelaskan faktor penyebab tingginya keanekaragaman hayati di lampung; Menjelaskan keanekaragaman hayati flora dan fauna di lampung; Menganalisis 
ancaman punahnya keanekaragaman hayati di Indonesia; Menjelaskan pelestarian sumber daya alam dan pemanfaatnya; Menjelaskan usahausaha pelestarian keanekargaman hayati. Capaian Pengetahuan Biodiversitas dilihat dari skor total jawaban benar siswa yang diperoleh.

Sikap peduli lingkungan siswa diukur dengan kuisioner yang berjumlah 30 pertanyaan dengan aspek meliputi sikap terhadap bumi, sikap terhadap flora dan fauna, sikap terhadap sampah.

Peneliti mendeskripsikan pengetahuan biodiversitas dan sikap peduli lingkungan siswa, kemudian melihat pengaruh pengetahuan tentang biodiversitas terhadap sikap peduli lingkungan di Sekolah Kawasan TNWK dengan di kota Bandar Lampung dengan uji regresi linier sederhana dengan bantuan program SPSS 17.0. Sedangkan untuk menentukan perbedaan pengetahuan biodiversitasdan sikap peduli lingkungan peserta didik di Sekolah Kawasan TNWK dengan di kota Bandar Lampung dengan uji independent sampel $t$ test dengan bantuan program SPSS 17.0.

\section{HASIL DAN PEMBAHASAN}

Pengetahuan tentang biodiversitas dan sikap peduli lingkungan peserta didik di SMA Negeri 1 Labuhan Maringgai Lampung Timur (sekolah kawasan TNWK) dan SMA Negeri 14 Bandar Lampung (sekolah dikota Bandar Lampung) di ukur menggunakan soal pengetahuan tentang biodiversitas yang telah divalidasi sebanyak 22 soal dan kuisioner sikap peduli lingkungan yang telah divalidasi sebanyak 30 pernyataan. Hasil penelitian pengetahuan tentang biodiversitas dan sikap peduli lingkungan disajikan dalam bentuk tabulasi pada Tabel 1 berikut.

Tabel 1. Perbandingan skor pengetahuan dan sikap antara peserta didik yang berada di kawasan taman nasional (Sekolah A) dengan peserta didik di kawasan perkotaan (Sekolah B)

\begin{tabular}{|c|c|c|c|c|c|}
\hline \multicolumn{3}{|c|}{ Pengetahuan } & \multicolumn{3}{|c|}{ Sikap } \\
\hline \multirow{2}{*}{ Indikator } & \multicolumn{2}{|c|}{ Skor } & \multirow{2}{*}{ Indikator } & \multicolumn{2}{|c|}{ Skor } \\
\hline & Sekolah A & Sekolah B & & Sekolah A & Sekolah B \\
\hline 1 & 63 & 51 & 1 & 83 & 78 \\
\hline 2 & 39 & 45 & 2 & 81 & 83 \\
\hline 3 & 89 & 66 & 3 & 82 & 84 \\
\hline 4 & 56 & 61 & & & \\
\hline 5 & 78 & 68 & & & \\
\hline 6 & 62 & 66 & & & \\
\hline 7 & 53 & 51 & & & \\
\hline$\sum$ responden & 63 & 61 & Eresponden & 63 & 61 \\
\hline Rata-rata & 59 & 55 & Rata-rata & 82 & 79 \\
\hline St. Deviasi & 12 & 13 & St. Deviasi & 6 & 7 \\
\hline
\end{tabular}

Keterangan: indikator pengetahuan (1: Membedakan tingkatan keanekaragaman hayati tingkat gen, jenis dan ekosistem; indikator 2: Membedakan pengertian keseragaman dan keberagaman makhluk hidup; indikator 3: Menjelaskan faktor penyebab tingginya keanekaragaman hayati di lampung; indikator 4: Menjelaskan keanekaragaman hayati flora dan fauna di lampung; indikator 5: Menganalisis ancaman punahnya keanekaragaman hayati di indonesia; indikator 6: Menjelaskan pelestarian sumber daya alam dan pemanfaatnya; indikator 7: Menjelaskan usaha-usaha pelestarian keanekargaman hayati ) Indikator sikap (Kognisi: Pemahaman individu terhadap lingkungan; afeksi: Perasaan individu terhadap terhadap lingkungan; konasi: Kecenderungan untuk bertindak atau berperilaku terhadap lingkungan)

Dilihat dari segi akademik, sebagian besar peserta didik SMA Negeri 1 LabuhanMaringgai Lampung Timurdan SMA Negeri 14 Bandar Lampung memiliki kemampuan "tinggi", "sedang" hingga "rendah" dalam bidang akademik. Kriteria pengetahuan tentang biodiversitas peserta didik yang diambil melalui tes di SMA Negeri 1 Labuhan Maringgai Lampung Timur dan SMA Negeri 14 Bandar Lampung pada Tabel 2 berikut.

Merujuk pada Tabel 2 tersebut, diketahui bahwa data hasil tes pengetahuan tentang biodiversitas peserta didik di sekolah kawasan TNWK termasuk dalam kriteria "Sedang" yaitu 
dengan skor 60 sedangkan hasil tes pengetahuan tentang biodiversitas peserta didik di sekolah di kota Bandar Lampung termasuk dalam kriteria "Rendah" yaitu dengan skor 55 .

Kemudian, sikap peduli lingkungan peserta didik yang diambil melalui kuisioner di SMA
Negeri 1 Labuhan Maringgai Lampung Timur dan SMA Negeri 14 Bandar Lampung, rata-rata sikap peduli lingkungan disajikan pada Tabel 3 berikut:

Tabel 2. Perbandingan rata-rata kompetensi pengetahuan dan kriteria peserta didik tentang Bioediversitas di sekolah kawasan taman nasional (Sekolah A) dengan di kawasan perkotaan (Sekolah B)

\begin{tabular}{|c|c|c|c|c|}
\hline \multirow[b]{2}{*}{ Indikator yang diuji } & \multicolumn{2}{|c|}{ Sekolah A } & \multicolumn{2}{|c|}{ Sekolah B } \\
\hline & $\begin{array}{c}\text { Skor } \\
(\bar{x} \pm \operatorname{sem})\end{array}$ & $\mathbf{K r}$ & $\begin{array}{c}\text { Skor } \\
(\bar{x} \pm \text { sem) }\end{array}$ & $\mathbf{K r}$ \\
\hline $\begin{array}{l}\text { Membedakan } \\
\text { keanekaragaman hayati tingkat gen, } \\
\text { jenis dan ekosistem }\end{array}$ & $63 \pm 20$ & $\mathrm{~S}$ & $51 \pm 23$ & $\mathrm{R}$ \\
\hline $\begin{array}{l}\text { Membedakan pengertian keseragaman } \\
\text { dan keberagaman makhluk hidup }\end{array}$ & $38 \pm 31$ & $\mathrm{R}$ & $45 \pm 32$ & $\mathrm{R}$ \\
\hline $\begin{array}{l}\text { Menjelaskan faktor penyebab tingginya } \\
\text { keanekaragaman hayati di lampung }\end{array}$ & $89 \pm 32$ & $\mathrm{~T}$ & $66 \pm 48$ & $\mathrm{~S}$ \\
\hline $\begin{array}{l}\text { Menjelaskan keanekaragaman hayati } \\
\text { flora dan fauna di lampung }\end{array}$ & $56 \pm 35$ & $\mathrm{~S}$ & $61 \pm 28$ & $\mathrm{~S}$ \\
\hline $\begin{array}{l}\text { Menganalisis ancaman punahnya } \\
\text { keanekaragaman hayati di indonesia }\end{array}$ & $78 \pm 31$ & $\mathrm{~T}$ & $67 \pm 37$ & $\mathrm{~S}$ \\
\hline $\begin{array}{l}\text { Menjelaskan pelestarian sumber daya } \\
\text { alam dan pemanfaatnya }\end{array}$ & $62 \pm 38$ & $\mathrm{~S}$ & $66 \pm 45$ & $\mathrm{~S}$ \\
\hline $\begin{array}{l}\text { Menjelaskan usaha-usaha pelestarian } \\
\text { keanekargaman hayati }\end{array}$ & $53 \pm 34$ & $\mathrm{R}$ & $51 \pm 24$ & $\mathrm{R}$ \\
\hline Rata-Rata Skor & $60 \pm 12$ & $S$ & $55 \pm 13$ & $\mathrm{R}$ \\
\hline
\end{tabular}

Ket: $\mathrm{x}^{-}=$rata-rata; $\mathrm{Kr}=$ kriteria; $\mathrm{ST}=$ sangat tinggi; $\mathrm{T}=$ tinggi; $\mathrm{R}=$ rendah; $\mathrm{S}=$ sedang; $\mathrm{SR}=$ sangat rendah

Tabel 3. Perbandingan rata-rata kompetensi sikap dan kriteria peserta didik tentang Bioediversitas di sekolah kawasan taman nasional (Sekolah A) dengan di kawasan perkotaan (Sekolah B)

\begin{tabular}{|c|c|c|c|c|}
\hline & \multicolumn{2}{|c|}{ Sekolah A } & \multicolumn{2}{|c|}{ Sekolah B } \\
\hline & $\begin{array}{c}\text { Skor } \\
(\bar{x} \pm \text { sem })\end{array}$ & $\mathrm{Kr}$ & $\begin{array}{c}\text { Skor } \\
(\bar{x} \pm \operatorname{sem})\end{array}$ & $\mathrm{Kr}$ \\
\hline Aspek 1 & $83 \pm 8$ & ST & $78 \pm 9$ & $\mathrm{~T}$ \\
\hline Aspek 2 & $81 \pm 7$ & ST & $79 \pm 7$ & $\mathrm{~T}$ \\
\hline Aspek 3 & $82 \pm 7$ & $\mathrm{ST}$ & $81 \pm 8$ & ST \\
\hline $\begin{array}{l}\text { Rata- } \\
\text { rata }\end{array}$ & $82 \pm 6$ & ST & $79 \pm 7$ & $\mathrm{~T}$ \\
\hline
\end{tabular}

Ket Aspek 1: Pemahaman individu terhadap lingkungan; Aspek 2:Perasaan individu terhadap terhadap lingkungan; Aspek 3: Kecenderungan untuk bertindak atau berperilaku terhadap lingkungan)

Dengan demikian berdasarkan ketiga aspek yang terbagi menjadi tiga in-dikator, di sekolah kawasan TNWK capaian sikap peduli lingkungan peserta didik berada pada kriteria"sangat tinggi" dengan skor 82 begitu juga dengan sekolah di kota Bandar Lampung capaian 
sikap peduli lingkungan peserta didik berada pada kriteria "tinggi" dengan skor 79 . Berdasarkan hal tersebut, maka untuk menentukanperbedaan pengetahuan tentang biodiversitas dan sikap peduli lingkungan peserta didik maka dilakukan uji prasyarat yaitu uji normalitas dan uji homogenitas.

Uji normalitas dilakukan untuk mengetahui apakah data kedua kelompok tersebut berdistribusi normal atau tidak dan merupakan uji prasyarat untuk dapat melakukan uji independent sampel $t$ test. Pengujian normalitas dilakukan dengan uji Kolomogrov Smirnov. data dikatakan normal apabila Asmpy. Sig data $\geq$ tabel_kritis. Ber-dasarkan hasil perhitungan menggunakan SPSS versi 17 diperoleh data pada Tabel 4 seperti berikut:

Tabel 4. Hasil uji normalitas data dengan variabel pengetahuan tentang biodiversitas dan sikap peduli lingkungan peserta didik di sekolah kawasan taman nasional (Sekolah A) dengan di kawasan perkotaan (Sekolah B)

\begin{tabular}{|c|c|c|c|c|c|}
\hline \multirow{2}{*}{ Variabel } & \multicolumn{2}{|c|}{ Sekolah A } & \multicolumn{2}{|c|}{ Sekolah B } & \multirow{2}{*}{ Keterangar } \\
\hline & Asmpy. Sig. & Tabel $_{\text {kritis }}$ & Asmpy. Sig. & Tabel $_{\text {kritis }}$ & \\
\hline Pengetahuan tentang Biodiversitas & 0,200 & 0,170 & 0,200 & 0,173 & Normal \\
\hline Sikap Peduli Lingkungan & 0,200 & 0,170 & 0,179 & 0,174 & Normal \\
\hline
\end{tabular}

Tabel 5. Hasil uji homogenitas

\begin{tabular}{lccc}
\hline \multicolumn{1}{c}{ Variabel } & Sig & $\boldsymbol{\alpha}$ & Keterangan \\
\hline Pengetahuan tentang Biodiversitas & 0,965 & 0,05 & Homogen \\
\hline Sikap Peduli Lingkungan & 0,159 & 0,05 & Homogen \\
\hline
\end{tabular}

Informasi yang di dapat dari tabel diatas, dengan tabel kritis sebesar 0,170 untuk sekolah kawasan TNWK dan 0,173 untuk sekolah di kota Bandar Lampung, diperoleh hasil uji normalitas pengetahuan tentang biodiversitas dan sikap peduli lingkungan baik di sekolah kawasan TNWK maupun sekolah di kota Bandar Lampung diperoleh hasil Asmpy. Sig data $\geq$ tabel_kritis dengan begitu H_0 diterima dan H_1 ditolak yang artinya data berdistribusi normal. Uji homogenitas merupakan uji untuk mengetahui apakah kelompok peserta didik atau sampel yang berasal dari kedua kelompok tersebut dapat dikatakan bervarians sama (homogen) ataupun tidak. Pengujian homogenitas dilakukan dengan uji Levene statistic. Dikatakan homogen apabila $\mathrm{Sig} \geq$ 0,05.Berdasarkan hasil perhitungan menggunakan SPSS versi 17 diperoleh data pada Tabel 5.

Merujuk tabel diatas bahwasannya hasil perhitungan yang diperoleh dari data pengetahuan tentang biodiversitas dan sikap peduli lingkungan dari kedua kelompok sampel dengan Sig $\geq 0,05$, dengan begitu H_0 diterima dan $\mathrm{H} \_1$ ditolak yang berarti data varians homogen.

Setelah dilakukan uji prasyarat, selanjutnya dilakukan uji hipotesis untuk mengetahui perbedaan Pengetahuan tentang Biodiversitas dan sikap peduli lingkungan antara peserta didik sekolah di kawasan TNWK dengan sekolah di kota Bandar Lampung. Pengujian hipotesis dilakukan dengan uji Independent Sampel $t$ test. Sedangkan pengujian hipotesis untuk mengetahui pengaruh pengetahuan tentang biodiversitas terhadap sikap peduli lingkungan di sekolah kawasan TNWK dengan di kota bandar lampung dilakukan dengan uji regresi linier sederhana. Berdasarkan hasil pengujian dengan menggunakan SPSS versi 17, diperoleh data pada Tabel 7 sebagai berikut. 
Tabel 6. Hasil uji independent sampel t test Pengetahuan tentang Biodiversitas

\begin{tabular}{lccc}
\multicolumn{4}{c}{ dan Sikap Peduli Lingkungan } \\
Variabel & Sig.(2-tailed) & $\boldsymbol{\alpha}$ & Keterangan \\
\hline Pengetahuan tentang Biodiversitas & 0,000 & 0,05 & Signifikan \\
\hline Sikap Peduli Lingkungan & 0,006 & 0,05 & Signifikan \\
\hline
\end{tabular}

Tabel 7. Hasil uji regresi linier sederhana pengetahuan tentang biodiversitas dengan sikap peduli lingkungan antara peserta didik di sekolah kawasan taman nasional (Sekolah A) dan di kawasan perkotaan (Sekolah B)

\begin{tabular}{lccc}
\hline \multicolumn{1}{c}{ Sekolah } & Sig. & Keeratan Pengaruh & $\begin{array}{c}\text { Kontribusi pengetahuan } \\
\text { terhadap sikap }\end{array}$ \\
\hline Sekolah A & $0,000 \leq 0,05$ & 0,314 (rendah) & 0,098 \\
\hline Sekolah B & $0,308 \leq 0,05$ & 0,96 (sangat rendah) & 0,010 \\
\hline
\end{tabular}

Berdasarkan data pada Tabel 6, diketahui nilai signifikansi t_hitung pada output independent sampel $t$ test diperoleh nilai Sig.(2-tailed) sebesar 0,000 yang berarti $0,000 \leq 0,05$, maka sesuai dengan dasar pengambilan keputusan dalam uji independent sampel $\mathrm{t}$ test yang berarti $\mathrm{H} \_0$ ditolak dan $\mathrm{H} \_1$ diterima, artinya terdapat perbedaan antara rata-rata Pengetahuan tentang biodiversitas antara sekolah di kawasan TNWK dengan sekolah di kota Bandar Lampung. Kemudian, pada variabel sikap peduli lingkungan, diketahui nilai signifikansi t_hitung pada output independent sampel test diperoleh nilai Sig.(2-tailed) sebesar 0,006 yang berarti 0,006 $\leq$ 0,05 , maka sesuai dengan dasar pengambilan keputusan dalam uji independent sampel $t$ test yang berarti H_0 ditolak dan H_1 diterima, artinya terdapat perbedaan antara rata-rata sikap peduli lingkungan antara sekolah di kawasan TNWK dengan sekolah di Kota Bandar Lampung.

Setelah melakukan uji beda, pengujian berikutnya dilanjutkan dengan uji regresi yang bertujuan untuk mengetahui signifikansi hubungan antarvariabel, seperti yang terdapat pada Tabel 7.

Setelah dilakukan uji regresi linier, menunjukan bahwa nilai signifikansi t_hitung pada output regresi linier sederhana diperoleh nilai Sig.(2-tailed) sebesar 0,000 yang berarti $0,000 \leq 0,05$, maka sesuai dengan dasar pengambilan keputusan dalam uji regresi linier sederhana yang berarti $\mathrm{H} 0$ ditolak dan $\mathrm{H} 1$ diterima, artinya terdapat pengeruh yang signifikan pengetahuan tentang biodiversitas terhadap sikap peduli lingkungan di sekolah kawasan TNWK. Sedangkan nilai signifikansi t_hitung pada output regresi linier sederhana sekolah di Kota Bandar Lampung diperoleh nilai Sig.(2-tailed) sebesar 0,000 yang berarti $0,409 \leq 0,05$, maka sesuai dengan dasar pengambilan keputusan dalam uji regresi linier sederhana yang berarti H_1 ditolak dan H_0 diterima, artinya tidak terdapat pengaruh pengetahuan tentang bio-diversitas terhadap sikap peduli lingkungan di sekolah di Kota Bandar Lampung.

Penelitian ini menggunakan sekolah SMA Negeri 1 Labuhan Maringgai Lampung Timur. Sekolah ini merupakan sekolah yang terdekat dengan kawasan TNWK. Taman Nasional Way Kambas) adalah kawasan pelestarian, dimana terdapat kawasan penyangga di sekitarnya. Menurut data dan informasi yang diperoleh dari Tropical Forest Conservation Action (2016) Taman Nasional Way Kambas berbatasan langsung dengan 37 desa penyangga, yang terbagi 37 desa penyangga, yang terbagi menjadi 10 kecamatan dalam 2 kabupaten. Dari keseluruhan data tersebut, 24 desa sudah tergabung dalam Forum Rembug Desa Penyangga (FRDIP). Desa Labuhan Ratu Kecamatan Labuhan Ratu Lampung Timur merupakan salah satu desa penyangga Taman Nasional Way Kambas. Sedangkan di kota Bandar Lampung peneliti 
menggunakan SMA Negeri 14 Bandar Lampung karena dekat dengan pusat kota.

Kompetensi pengetahuan tentang biodiversitas peserta didik juga dilihat berdasarkan aspek indikatornya yaitu: Membedakan tingkatan keanekaragaman hayati tingkat gen, jenis dan ekosistem; Menjelaskan faktor penyebab tingginya keanekaragaman hayati di Lampung; Menjelaskan keanekaragaman hayati flora dan fauna di lampung; Menjelaskan pelestarian sumber daya alam dan pemanfaatnya; Menjelaskan usaha-usaha pelestarian keanekargaman hayatidi masing-masing sekolah baik kawasan TNWK maupun di kota Bandar Lampung menunjukan hasil yang lebih tinggi dibandingkan aspek lainnya dengan ratarata capaian ketujuh aspek berada pada kriteria "sedang" dan "rendah".

Merujuk pada Tabel 1 mengenai hasil tes kompetensi pengetahuan tentang biodiversitas tersebut peserta didik di SMA Negeri 1 Labuhan Maringgai Lampung Timur (sekolah kawasan TNWK) termasuk dalam kriteria "tinggi", sedangkan kompetensi penge-tahuan tentang biodiversitas peserta didik di SMA Negeri 14 Bandar Lampung (sekolah di kota Bandar Lampung) termasuk dalam kriteria "sedang", dengan demikian berarti tingkat pengetahuan tentang bio-diversitas peserta didik di SMA Negeri 1 Labuhan Maringgai Lampung Timur lebih tinggi dibandingkan dengan SMA Negeri 14 Bandar Lampung.

Hasil sikap peduli lingkungan peserta didikpada Gambar 2, berdasarkan ketiga aspek yang terbagi menjadi tiga indikator, di SMA Negeri 1 Labuhan Maringgai Lampung Timur (sekolah kawasan TNWK) capaian sikap peduli lingkungan peserta didik berada pada kriteria"sangat tinggi" begitu juga di SMA Negeri 14 Bandar Lampung (sekolah dikota Bandar Lampung) capaian sikap peduli lingkungan peserta didik berada pada kriteria "tinggi". Nilai sikap dikedua sekolah mempunyai hasil yang tidak terlalu berbeda satu sama lain.

Berdasarkan hasil penelitian di SMA Negeri 1 Labuhan Maringgai Lampung Timur dan SMA Negeri 14 Bandar Lampung, untuk menentukan perbedaan pengetahuan tentang biodiversitas dan sikap peduli lingkungan antara peserta didik sekolah kawasan TNWK dengan sekolah di kota Bandar Lampung maka dilakukan uji hipotesis, sebelum melakukan uji hipotesis maka dilakukan uji prasyarat yaitu uji normalitas dan uji homogenitas data.

Data pada penelitian ini telah normal dan homogen sehingga dapat dilakukan uji independent sampel $t$ test. Diperoleh hasil uji hipotesis menggunakan uji independent sampel $\mathrm{t}$ testpada tabel 20 diperoleh nilai signifikansi t_hitung nilai Sig.(2-tailed) sebesar 0,000 yang berarti $0,000 \leq 0,05$, berarti H_0 ditolak dan H_1 diterima, artinya terdapat perbedaan antara rata-rata pengetahuan tentang biodiversitas antara sekolah kawasan TNWK dengan sekolah di kota Bandar Lampung. Kemudian untuk sikap peduli lingkungan peserta didikpada tabel 21 diketahui nilai signifikansi t_hitung nilai Sig.(2-tailed) sebesar 0,006 yang berarti $0,006 \leq 0,05$, yang berarti H_0 ditolak dan $\mathrm{H} \_1$ diterima, artinya terdapat perbedaan antara rata-rata sikap peduli lingkungan antara sekolah dengan kawasan TNWK dengan sekolah di kota Bandar Lampung.

Dari hasil penelitian, diketahui bahwaterdapat perbedaan antarapengetahuan tentang biodiversitas dan sikap peduli lingkungan peserta didik kelas $\mathrm{X}$ sekolah kawasan TNWK dengan sekolah di kota Bandar Lampung. Terjadinya perbedaan pengetahuan tentang biodiversitas dan sikap peduli lingkungan peserta didik di sekolah kawasan TNWK dengan di kota Bandar Lampung salah satu faktor yang menyebabkan adalah tidak menggunakan TNWK karena terbatasnya waktu dan jarak tempuh yang cukup jauh. Materi pedendidikan lingkungan hidup yang di terapkan di kurikulum yang pada mata pelajaran biologi salah satu materi pokok yang terkait adalah biodiversitas. Dalam pembelajaran biodiversitas di arahkan untuk ketercapaian KD 3.2 Menganalis berbagai tingkat keanekaragaman hayati di indonesia beserta ancamannya dan pelestariannya beserta 
ancamanya. Untuk mencapainya di butuh lingkungan sekitar sebagai sumber belajar. Lingkungan sekitar yang dapat di-gunakan di sekolah kawasan TNWK adalah flora dan fauna yang terdapat di kawasan pelestaraian. Sedangkan sekolah yang berada di kota yaitu kawasan industri, pabrik, dan mall. Menurut Kemendikbud, mengenai pemanfaatan lingkungan sekolah sebagai sumber belajar sekolah di perkotaan dapat menggunakan sumber belajar berupa lingkungan sekitar diantaranya: kawasan industri, pabrik, mall, dan lain sebagainya. Terkecuali hutan karena relatif jauh dari lokasi sekolah. Hal ini didukung oleh penelitian (Insani. 2016: 92) bahwa peserta didik di kota Malang mengalami kesulitan dalam penggunaan sumber belajar IPA seperti hutan karena jarak tempuh antara sekolah dan kawasan hutan yang cukup jauh. Oleh sebab itu, pendidik hanya menggunakan sumber belajar berupa buku paket dan internet saja.

Berdasarkan hasil penelitian uji regresi linier sederhana, diperoleh nilai Sig.(2-tailed) di sekolah kawasan TNWK sebesar 0,000 yang berarti $0,000 \leq 0,05$. Sedangkan nilai Sig.(2tailed) yang diperoleh sekolah di Kota Bandar Lampungsebesar 0,308 yang berarti $0,308 \leq$ 0,05 . Hal ini menunjukkan bahwa pengetahuan tentang biodiversitas peserta didik di sekolah kawasan TNWK berpengaruh terhadap sikap peduli lingkungannya. Sedangkan pengetahuan tentang biodiversitas peserta didik di sekolah kota Bandar Lampung tidak berpengaruh terhadap sikap peduli lingkungan. Hal ini dapat membuktikan bahwa kawasan TNWK berperan dalam pendidikan, yaitu dapat meningkatkan pengetahuan tentang biodiversitas dan sikap peduli lingkungan. Hal ini sesuai dengan Departemen Kehutanan (2002: 22) Taman nasional adalah kawasan pelestarian alam yang mempunyai ekosistem asli, dikelola dengan sistem zonasi yang dimanfaatkan untuk tujuan penelitian, ilmu pengetahuan, pen-didikan, menunjang budidaya, pari-wisata, dan rekreasi. Hal ini juga di dukung oleh (Surbakti, 2015: 67) bahwa pengetahuan mengenai keanekaragaman hayati merupakan salah satu cara untuk mencapai pendidikan. Dimana peng-gunaan pengetahuan mengenai ke-anekaragaman hayati tersebut, dapat meningkatkan pengetahuan sehingga menimbulkan inovasi salah satunya sikap peduli masyarakat (peserta didik) terhadap lingkungan dan pentingnya nilai-nilai keanekaragaman hayati. Semakin tinggi nilainilai pengetahuan maka akan semakin tinggi tingkat kesadaran masyarakat akan keanekaragaman hayati dan lingkungannya.

\section{SIMPULAN, SARAN, DAN REKOMENDASI}

Terdapat perbedaan pengetahuan tentang biodiversitas pada peserta didik di Sekolah Kawasan TNWK dengan di Kota Bandar Lampung. Terdapat perbedaan sikap peduli lingkungan pada peserta didik di Sekolah Kawasan TNWK dengan di Kota Bandar Lampung. Terdapat pengaruh antara pengetahuan tentang biodiversitas ter-hadap sikap peduli lingkungan peserta didik di Sekolah Kawasan TNWK.Tidak terdapat pengaruh antara pengetahuan pengetahuan tentang biodiversitas terhadap sikap peduli lingkungan peserta didik di sekolah Kota Bandar Lampung.

\section{DAFTAR PUSTAKA}

Afrianti, S. (2012). Peningkatan Pemahaman Konsep Grafik Trigonometri Siswa SMK Melalui Penemuan Terbimbing Melalui Penemuan Terbimbing Berbantuan Software Autograph. (Online). ejournal.unimed.ac.id, Diakses pada 21 April 2018.

Arikunto, S. (2010). Prosedur Penelitian Suatu Pendekatan Praktik. Jakarta: Rhineka Cipta.

Bimber, B. (2003). Information and American Democracy: Technology in Evolution of Political Power. Cambridge: Cambridge University Press.

Chiras, D. (1988). Enviromental Science. California: The Benyamin Coming Pub. Co. 
Departemen Kehutanan. (2002). Seleksi Pohon Plus Booklet. Sumedang. Balai Pembenihan Tanaman Hutan Jawa dan Madura.

Hamzah. (2004). Model Pembelajaran: Menciptakan Proses Belajar Mengajar yang Kreatif dan Efektif. Jakarta: PT. Bumi Aksara.

Indrawan, M., dan Primack, R.B. (2012). Biologi Konservasi. Edisi Revisi. Jakarta: Yayasan Pustaka Obor Indonesia.

Insani, M.D. (2016). Studi Pendahuluaan Identifikasi Kesulitan dalam Pembelajaran pada Guru IPA SMP Sekota Malang. Jurnal Pendidikan Biologi. Malang.

Ismail, M. (2010). Kinerja dan Kopetensi Guru dalam Pembelajaran. Bandung: Lentera Pendidikan.

Kadous, K. (2000). The Effects of Audit Quality and Consequence Severity on Juror Evaluations of Auditor Responsibility for Plaintiff Losses. The Accounting Review. Vol. 75. No. 3. pp. 327-341.

Keraf. (2002). Etika Lingkungan. Jakarta: Buku Kompas.

Nazir, M. (2009). Metode Penelitian. Jakarta: Ghalia Indonesia.

Rifanz. 2017. TNWK Lampung: (http://tamannasional-waykambas/tentang/rifanzblogspot.html). diakses pada 24 April 2018 pukul 21.10 WIB.

Skinner, F.B. 2000. Behavior as a Learning Theory Available From Behaviorism.

Sudaryono, M., dan Rahayu. (2013). Pengembangan Instrumen Penelitian Pendidikan. Yogyakarta: Graha Ilmu.

Surbakti, A. (2015). Pendidikan Kependudukan dan Lingkungan Hidup. Yogyakarta: Graha Ilmu.

Wiratno. dkk. (2001). Berkaca di Cermin Retak: Refleksi Konservasi dan Implikasi Bagi Pengelolaan Taman Nasional. The Gibbon Foundation Indonesia. 